\title{
URBAN GEOMORPHOLOGY IN COASTAL ENVIRONMENT: MAN-MADE MORPHOLOGICAL CHANGES IN A SEASIDE TOURIST RESORT (RAPALLO, EASTERN LIGURIA, ITALY)
}

\author{
Pierluigi Brandolini ${ }^{1}$, Francesco Faccini ${ }^{1}$, Guido Paliaga ${ }^{2}$, Pietro Piana ${ }^{3}$ \\ ${ }^{1}$ Department of Earth, Environment and Life Sciences, University of Genoa, Italy \\ ${ }^{2}$ Research Institute for Geo-hydrological Protection of Turin of the Italian National Research Council, Italy \\ ${ }^{3}$ School of Geography, University of Nottingham, United Kingdom
}

Manuscript received: May 08, 2017

Revised version: June 26, 2017

\begin{abstract}
Brandolini P., Faccini F., Paliaga G., Piana P. Urban geomorphology in coastal environment: man-made morphological changes in a seaside tourist resort (Rapallo, eastern Liguria, Italy). Quaestiones Geographicae 36(3), Bogucki Wydawnictwo Naukowe, Poznań, pp. 97-110. 15 figs.

ABSTRACT: This research focuses on the reconstruction of the morphological modifications of the coastal floodplain of Rapallo (Eastern Liguria, NW Italy) due to human intervention since the eighteenth century. By the second half of the nineteenth century Rapallo became a popular tourist destination: as a consequence, the urban development of the floodplain started and became very intense after Second World War, strongly modifying former landforms.

The study was carried out using multi-temporal cartographic and photographic comparison, the analysis of geo-thematic cartography and documentation from the Basin Master Plan and the town plan of Rapallo, the interpretation of cores from regional database and field data from direct urban surveys. Man-made landforms were mapped and classified using the new geomorphological legend which is in progress in the framework of the Working Groups on "Cartography" and "Urban Geomorphology" of the Italian Association of Physical Geography and Geomorphology (AIGEO). The main significant morphological changes were stream diversions and channeling, excavations and filling, quarry activities, embankments along the shoreline and overurbanization. Human interventions, in addition to local geomorphological and climate features, increased flood hazard and risk, which historically affected the city of Rapallo.
\end{abstract}

KEY WORDS: Urban Geomorphology; Man-made landforms; Tourism impact; Flood risk; Rapallo

Corresponding author: Pierluigi Brandolini,brando@unige.it

\section{Introduction}

Since the second half of the nineteenth century, Italy went through a significant urban growth and morphological changes. Before the mid-nineteenth century, urban development was almost totally conditioned by the morphology of territory, following former coastal landforms such as bays, gulfs, promontories, etc. (Terranova et al. 2000). Since the second half of the nineteenth century important landscape modifications occurred, particularly due to the construction of new roads and infrastructures but also buildings; these initially interested large cities and successively they involved minor settlements. Due to socio-economic changes, the depopulation of countryside from the 1960s resulted in a significant and undisciplined urban expansion, often impacting on geomorphological processes and dynamics. Urban growth in Italy and Liguria reached its top in the 1960s and 1970s, involving small towns characterised by natural and landscape values, particularly 
along the coast (Laureti et al. 1996). This sudden urban growth changed the territory not only in terms of soil consumption along the floodplains and surrounding slopes but also in terms of coastline and drainage network modifications, slope excavations and fillings. Today man-made landforms are the most significant morphogenetic feature along the Ligurian coast.

In this context a new line of research on urban geology and geomorphology emerged, alongside with a new attention to geodiversity in urban landscapes (Cimmino et al. 2004, Bathrellos 2007, Del Monte et al. 2013, 2016). Human modifications in urban environments determine the cityscape (Chengtai 1996). Urban geomorphology is the study of human intervention as a physical process of change where humans modify natural landforms transforming them into an anthropogenic landscape (Cooke 1976, Cooke et al. 1982). In such context, urban geomorphology is the surface component of urban geology (Coates 1974, 1976).

This research focuses on the morphological modifications of the Rapallo coastal floodplain since the eighteenth century, with the aim to support land planning and management within geo-hydrological risk evaluation.

The city of Rapallo, today part of Genoa's Metropolitan Area, is located in the Eastern Riviera of Liguria (Fig. 1) and it counts 30,000 inhabitants. From the first decades of the nineteenth century Rapallo was a well-known tourist resort but in the 1970s it became a symbol of irrational urbanization. Today the Italian term rapallizzazione indicates a process of bad quality urban modification and uncontrolled urban growth due to property speculation.

The final goal of this paper is to identify the anthropic landforms of Rapallo coastal zone in order to produce a novel map of Anthropocene, intended as a new interval of geological time in which human influence on Earth and its geological record dominates over natural processes (Crutzen 2002, Waters et al. 2016, Brown et al. 2017). Manmade landforms were mapped using the legend proposed by the Italian Association of Physical Geography and Geomorphology (AIGEO).

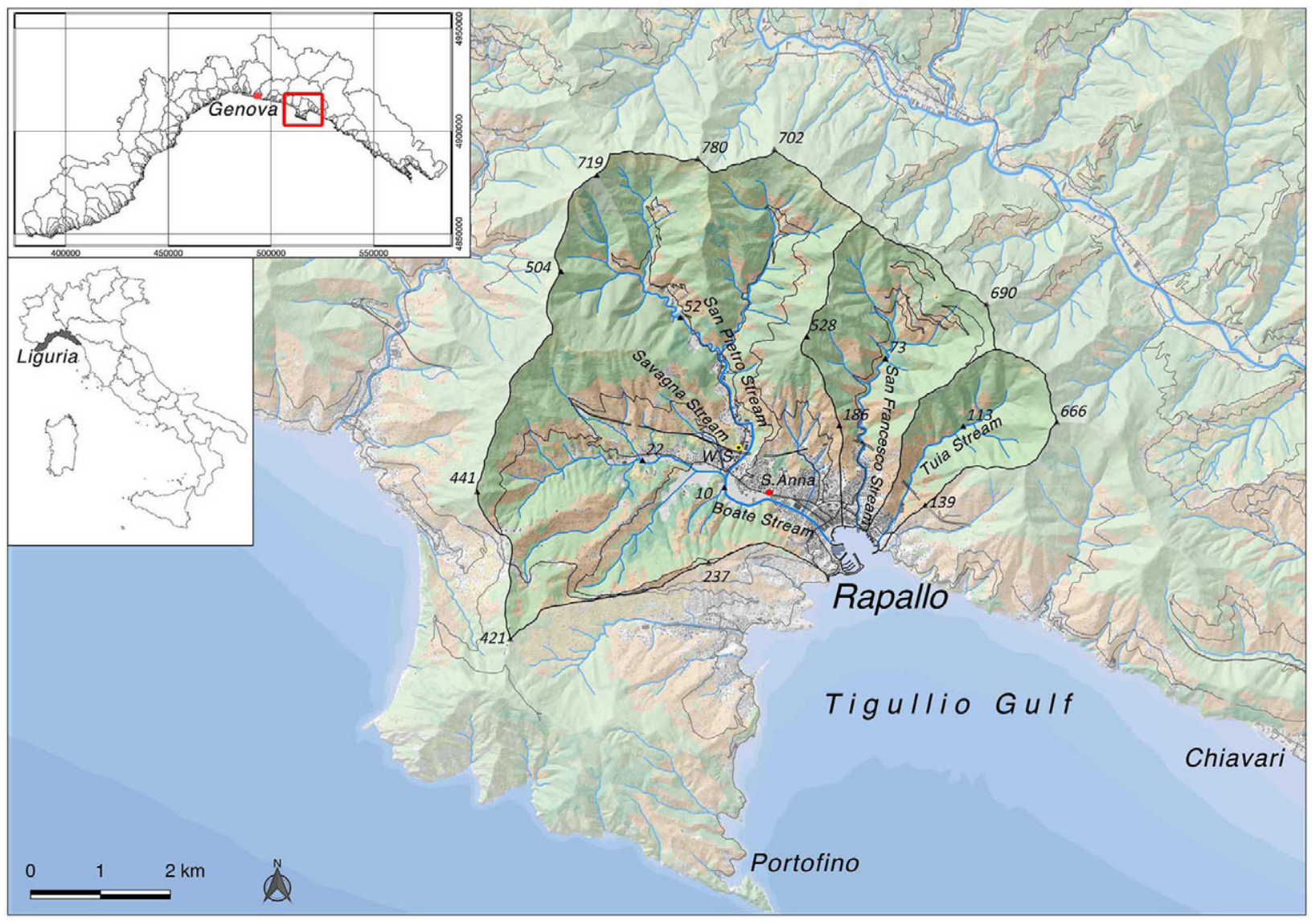

Fig. 1. Location map of the study area (W.S.: S. Pietro weather station). 

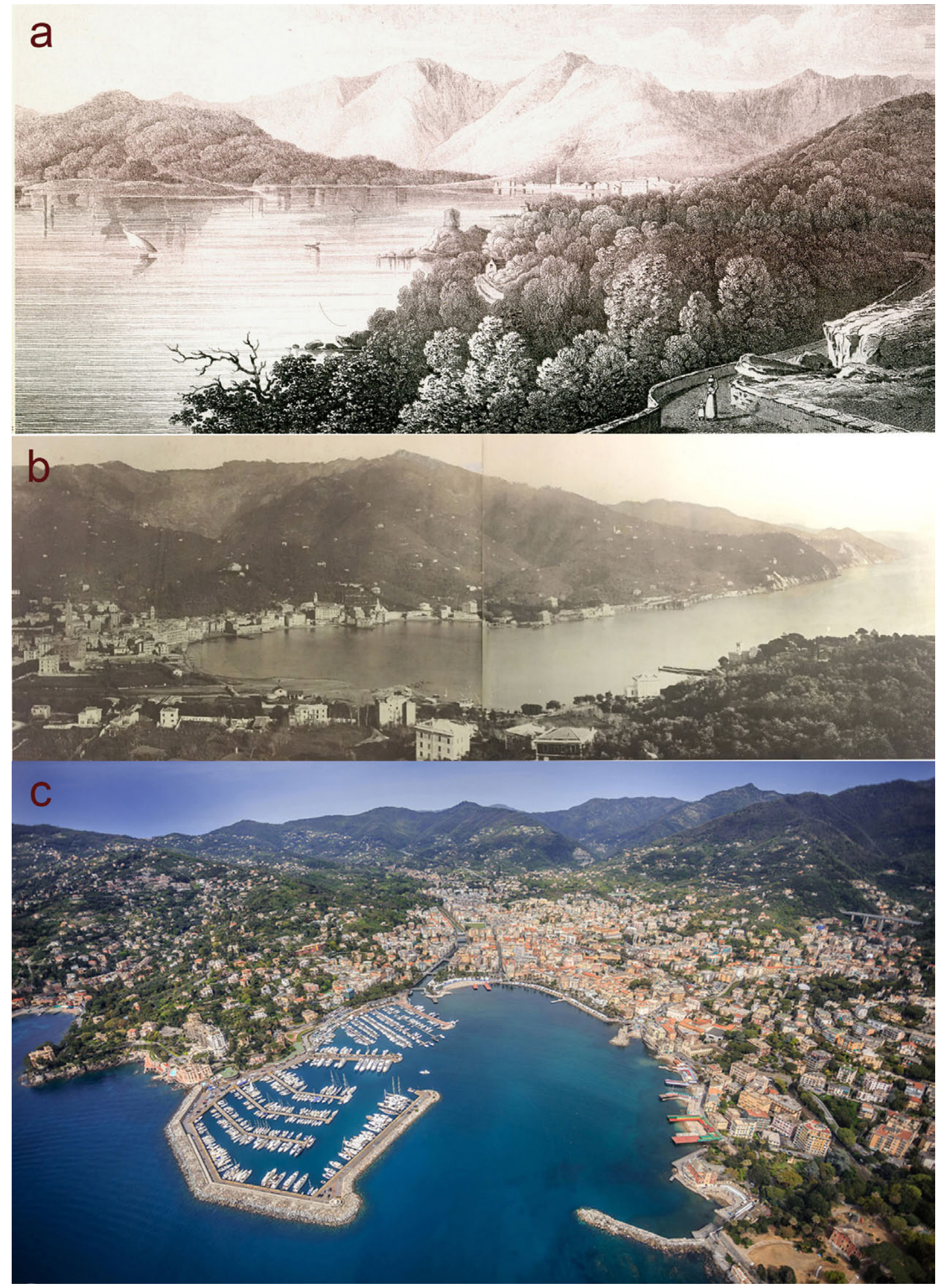

Fig. 2. Panoramic views of Rapallo coastal plain.

a) engraving dated back 1820 by E.F. Batty; b) photo dated back at the beginning of twentieth century (after Rapallo Municipality Archive); c) present day aerial photo by L. Sartori. 


\section{Study area}

The coastal floodplain of Rapallo is located in the innermost part of the Tigullio Gulf; it is c. $1 \mathrm{~km}$ wide and it breaks a stretch of coastline which is otherwise characterised by high rocky cliffs (Fig. 2). The setting of the floodplain and the rocky coast nearby is conditioned by two tectonic lineations. The main axis of floodplain and the stretch of coast between Rapallo and Zoagli follow the main lineation, which lies in a WNW-ESE direction, while minor tributary valleys and the stretch of coast between Rapallo and Portofino are oriented orthogonally to the former tectonic lineation (Fig. 3). The floodplain length is c. $3 \mathrm{~km}$, with an average width of 400-500 $\mathrm{m}$ and an overall surface just $>2 \mathrm{~km}^{2}$.
The floodplain is almost entirely constituted by alluvial deposits of the Boate Stream, which flows into the sea in the SW sector of the Rapallo bay, with a catchment of c. $26 \mathrm{~km}^{2}$. The San Francesco and Tuia streams, whose mouth is in the opposite side of the bay and have a catchment of respectively 6 and $2.5 \mathrm{~km}^{2}$, contribute to the formation of the coastal floodplain as well. With respect to the size of the floodplain and catchment the alluvial deposits have significant thickness (up to $25 \mathrm{~m}$ ): the deposits are made up of a sequence of clay, silt, peats, sands and gravels. This stratigraphy is associated to swampy deposits with transitions between marine and fluvial domain due to sea level oscillations in the Holocene (Brandolini, 1994). Moreover traces of some fluvial and marine terraces were found
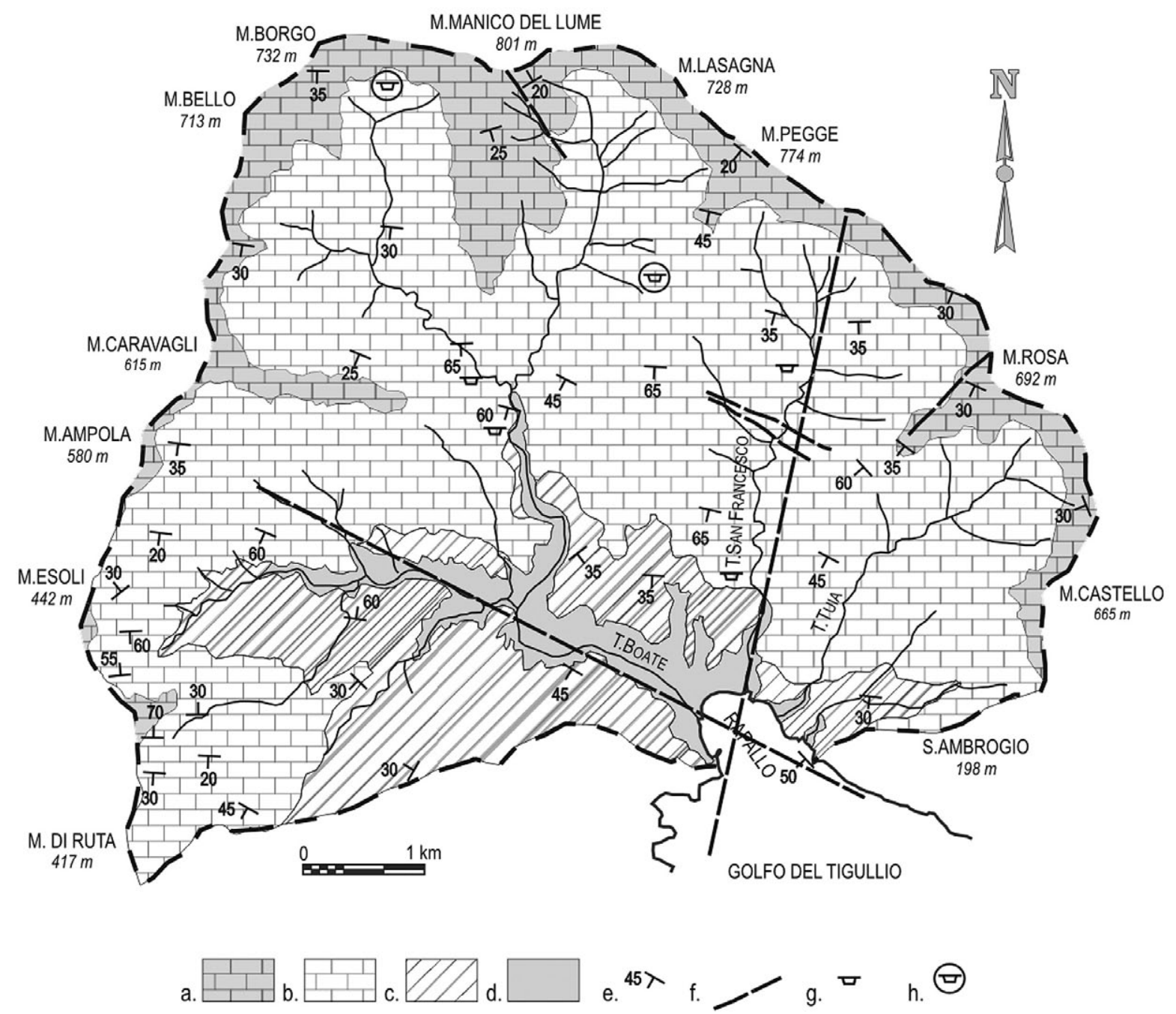

Fig. 3. Geological-geomorphological sketch map of Rapallo catchments.

a) Flysch of Mt. Antola, mainly in outcrop; b) eluvial covers; c) colluvial deposits; d) alluvial deposits; e) bedding attitude; f) fault or tectonic lineation; g) limestone quarry; h) slate underground quarry. 
along the slopes surrounding the floodplain at altitudes between 15 and $80 \mathrm{~m}$ a.s.l., alongside with triangular facets, which indicate the variations of the base level.

From a geological point of view the area is characterised by Mt. Antola Formation belonging to the homonymous tectonic units (Upper Cretaceous), mainly consisting of marly limestones, occasionally silty, with thin interlayers of shales. Although the Antola Unit has been affected by several deformations, it shows a general asset of layers with SW dip direction and dip angle ranging between $30^{\circ}$ and $60^{\circ}$ (Marini 1981).

Rapallo is characterised by a Mediterranean climate with dry and hot summers, relatively mild winters and abundant precipitation concentrated in autumn and spring (Sacchini et al. 2012). Between 1950-1989 the weather station of San Pietro di Novella (13 m a.s.1.) recorded a mean annual temperature of c. $15^{\circ} \mathrm{C}$, an average rainfall of $1400 \mathrm{~mm}$ and 90 rainy days (> $1 \mathrm{~mm}$ ). Detailed weather observations carried out in Genoa's Metropolitan Area underlined some climate trends: the mean annual temperature is increasing, while the number of rainy days shows a noteworthy reduction. On the contrary, the annual rainfall does not show significant changes and therefore, the daily rainfall rate is on the rise (Brandolini et al. 2012, Faccini et al. 2015, 2017).

\section{Material and methods}

Firstly the research was carried out collecting, analysing, re-elaborating and summarising previous geographical and geomorphological studies on the Rapallo area (Scarin 1959, Cortemiglia, Terranova 1974, Ballardini 1994, Brandolini 1994, 1995) and all the geo-thematic documentation and cartography, available from the Basin Master Plan for Geo-hydrological reduction and from Rapallo Municipality Town Plan (Città Metropolitana di Genova 2015, Comune di Rapallo 2014).

The second stage of research involved detailed research in historical archives and cartographical comparison of ancient, recent and current topographical maps (Luino et al. 2016). This allowed a better comprehension of the original morphology of the territory prior the urbanization of the second half of the nineteenth century, making it possible to identify the most significant morphological modifications, such as fillings and excavation along the floodplain and surrounding slopes and drainage network and coastline modifications.

The most significant cartographic documents for the purpose of this study were the maps from: Italian Military Geographical Institute (IGMI) archive $(1: 9,450$ scale manuscript maps from 18151827, 1:25,000 scale topographical maps from 1878-1939); Archivio di Stato di Genova (maps by Matteo Vinzoni of both the middle and late eighteenth century); Rapallo Municipality Archive (nineteenth century, early twentieth century and 1960s maps); Liguria Region Administration Archive (maps of 1984-2011).

The interpretation of aerial photography mainly focussed on images available between 1930s and 1980s: historical flights by IGMI (1936), RAF (1944), Liguria Region Administration (1973/74).

Lastly on-site geomorphological survey in urban environment involved large scale morphological observations (Ellison, 1993, Eyles, 1997). These were aimed at more detailed mapping of erosional and accumulation landforms due to human intervention, such as the identification of fillings with significant thickness. This operation was facilitated by the stratigraphic information derived from regional boreholes database.

In order to identify and map at large scale $(1: 5,000)$ the morphological modification following human intervention, the new geomorphological legend which is under development in the framework of the Working Groups on "Cartography" and "Urban Geomorphology" of the Italian Association of Physical Geography and Geomorphology (AIGEO) was used (Gruppo Nazionale Geografia Fisica e Geomorfologia 1993, Servizio Geologico Nazionale 1994).

The collected data and their interpretation allowed us to produce a preliminary map of the Anthropocene of Rapallo floodplain and its surroundings.

\section{Results}

The geomorphological landscape of Rapallo in the eighteenth century was reconstructed using the maps by Vinzoni, dated 1723 and 1773. The coastal zone was featured by the presence of the main course of the Boate Stream, free to wander in its floodplain, and by some other minor 
creeks (Fig. 4, 5). The inland area, next to the Boate Stream mouth, in the SW part of the bay, was characterized by a wide swampy area used as freight yard. The shoreline presented two sectors of rocky coast that delimited the bay respectively at NE and SW, where a c. $80 \mathrm{~m}$ long pier (Molo Langano) was present.

A c. $250 \mathrm{~m}$ long beach stretched between the mouth of the Boate Stream and the medieval settlement of Rapallo in the northern side of the bay. Smaller beaches just nearby the San Francesco Stream mouth were present too. The surrounding slopes were featured by agricultural terraces for olive groves, vineyards and fruit orchards, that were cultivated in the floodplain too.

The geomorphological setting of the floodplain and its land-use remained almost unchanged until the first decades of the nineteenth century. In 1826 the construction of the road to Santa Margherita Ligure-Portofino made it necessary to divert the river bed of the Boate Stream c. $70 \mathrm{~m}$ towards $\mathrm{N}$ (Fig. 6); the new stretch of the river was channelled and narrowed, while the new mouth is today where the previous beach was. The presence of a bridge ("Ponte di
Annibale") along the above mentioned road provides evidence of the former course of Boate Stream before nineteenth century.

Between 1859/60 significant embankments were carried out along the shoreline between the mouth of Boate Stream and the pier Molo Langano, in order to build a shipyard: these works determined the shoreline advance, the narrowing of Boate Stream mouth and the filling of former mouth.

Between 1868/1870 the building of the Genova-Pisa railway line took place: the railway track, which partly occupied the riverbed of the Boate, San Francesco and Tuia streams, was developed by the construction of 30-40 m wide and up to $5 \mathrm{~m}$ high embankments along the floodplain and by rock excavations, such as in the area of railway station, along the foothill slopes.

These morphological modifications are today identifiable by the presence of high retaining walls as in the case of the former civil hospital (the old S. Agostino convent), today separated from the foothill by the railway station.

Overall, the urban development of Rapallo up to the late nineteenth century was moderate:

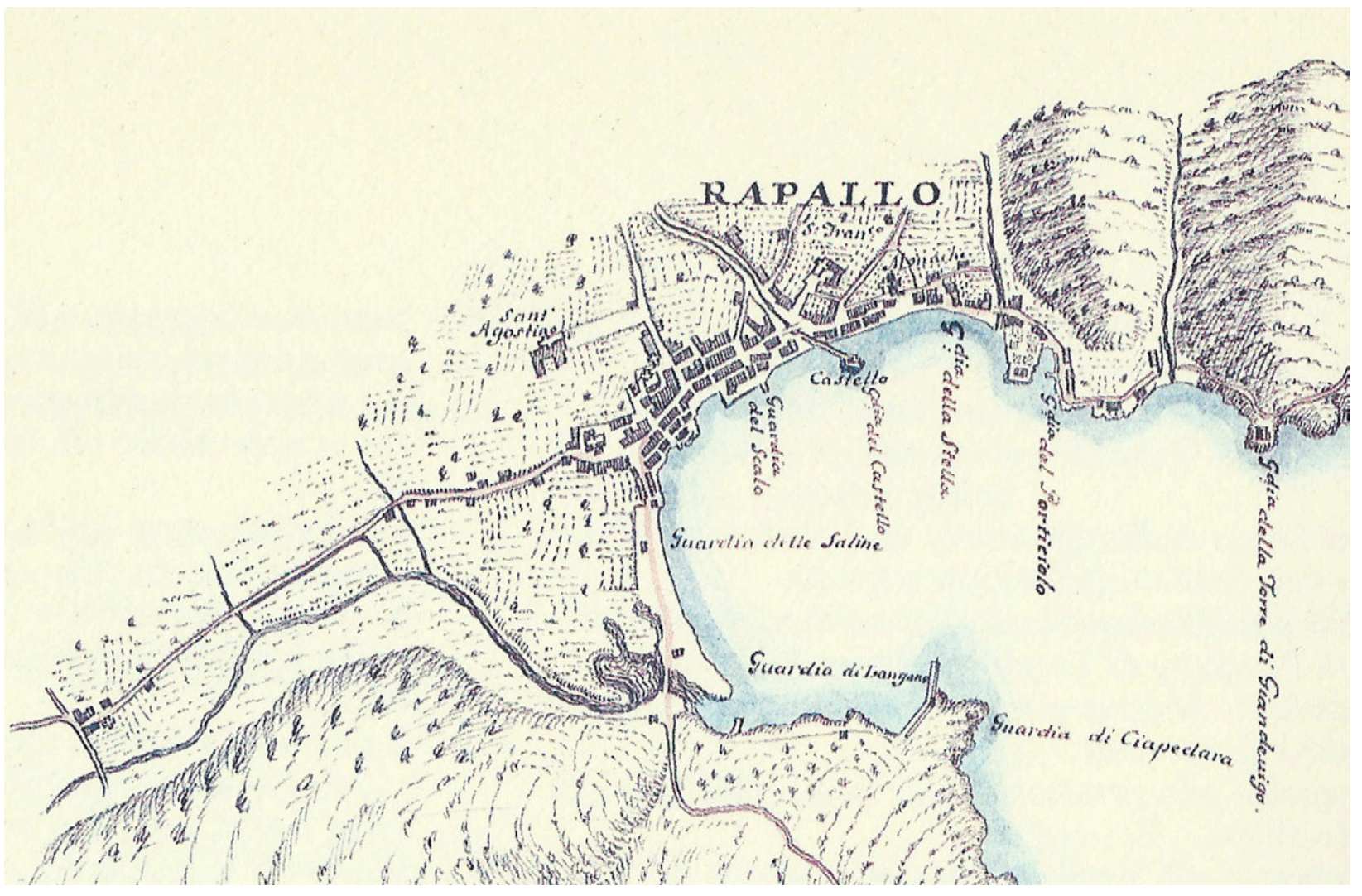

Fig. 4. Rapallo in the early eighteenth century (after Matteo Vinzoni map, 1722-23). 


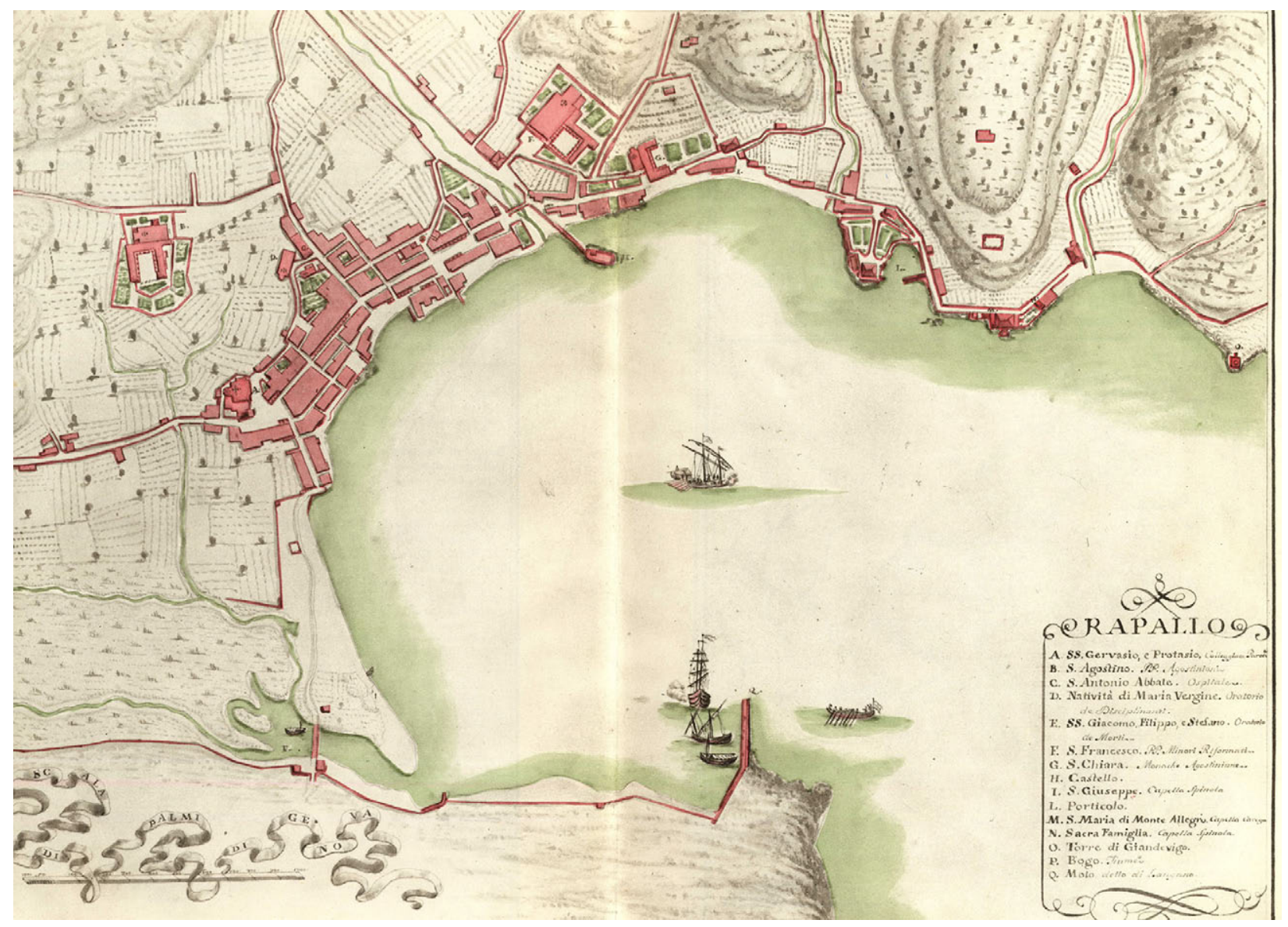

Fig. 5. Rapallo in the late eighteenth century (after Matteo Vinzoni map, 1774).

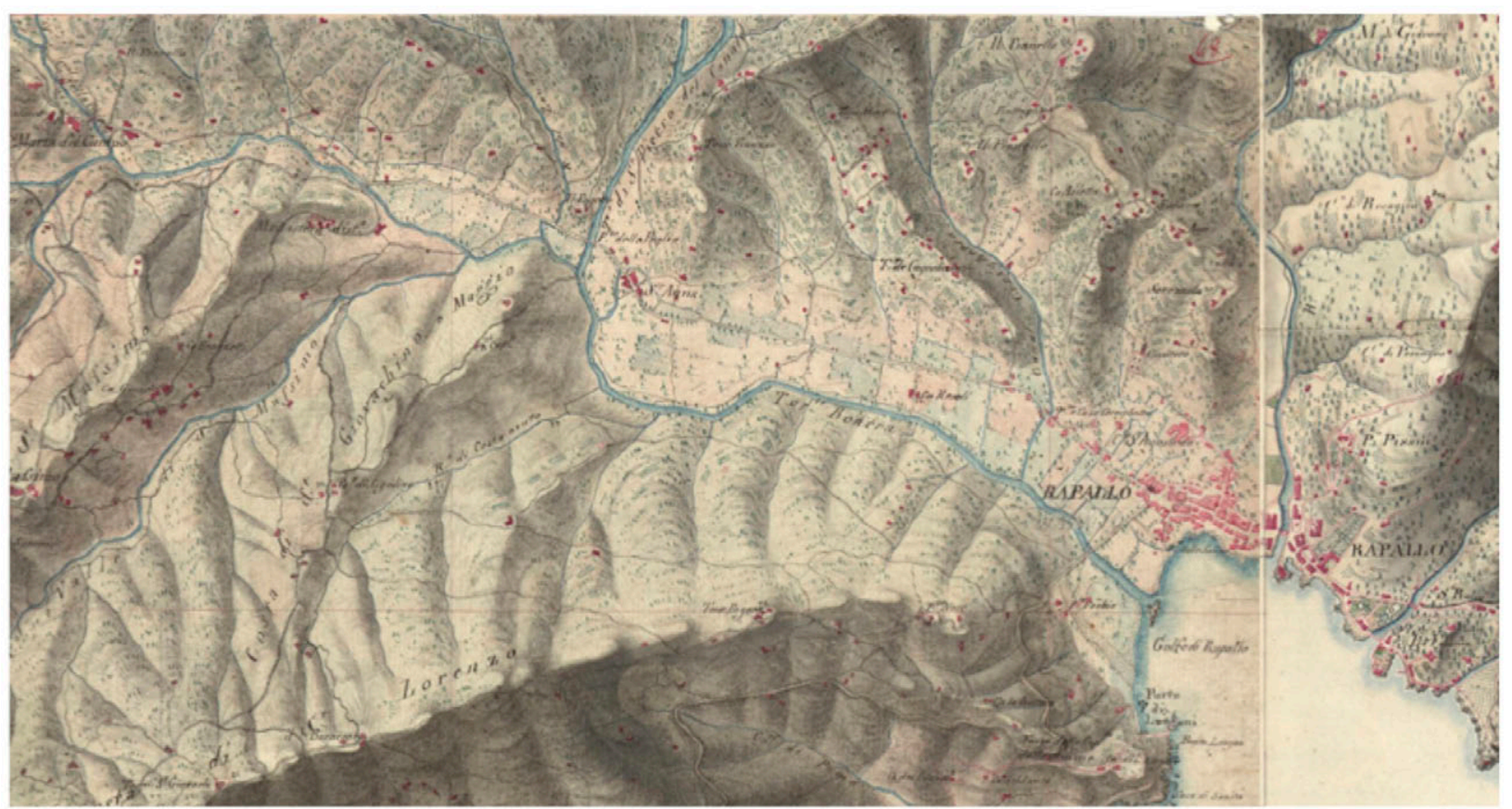

Fig. 6. Rapallo in the early nineteenth century (after Stati Sardi di Terraferma map, 1815-1823, from IGMI Archives). 


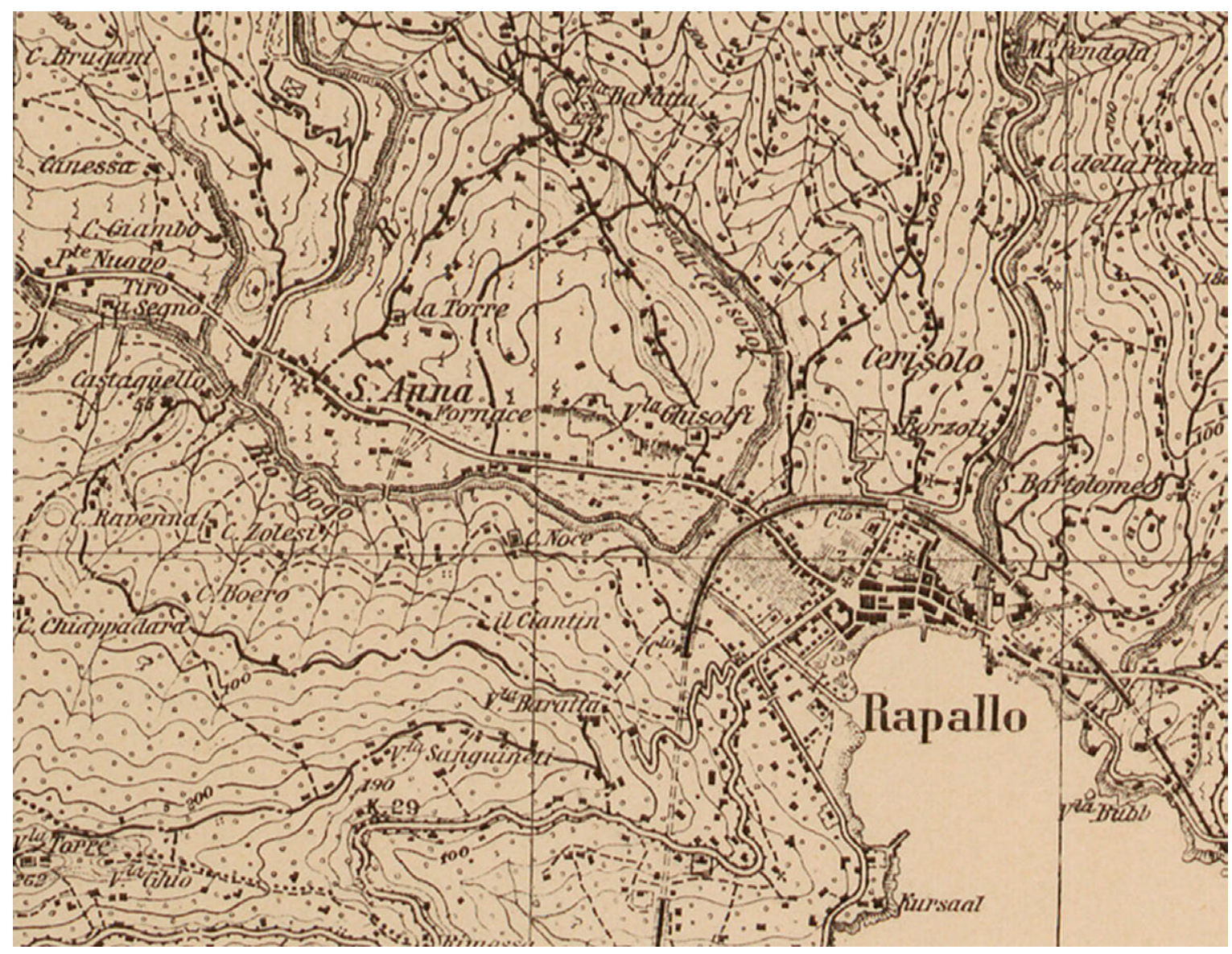

Fig. 7. Rapallo flood plain in the 1907s (after 1.25.000 scale map, IGMI Archives).

only a limited expansion towards $\mathrm{W}$ is observed, in an area which was previously conditioned by the presence of swamps and open pit and foothill-quarries for the extraction of clay for bricks in the Sant'Anna area (Fig. 7).

Today their location is identifiable through the analysis of historical cartography and boreholes. The stratigraphy of Sant'Anna area, in a clayey floodplain, shows filling thickness of 5-10 m: this is due to old clay pit quarries, which were mainly filled with the rubbles of buildings destroyed during the wars of the first half of the twentieth century.

The reclamation of the floodplain was completed at the end of nineteenth century and from 1919 river rectification interventions were carried out along the Boate Stream up to its confluence with S. Maria and S. Pietro Streams; these included the construction of concrete levees which narrowed the flow section of the Boate Stream.

During the first decades of the twentieth century, following the tourism development, new villas and hotels were built in the western side of the coastal floodplain (Fig. 8). By 1930, the area between the shoreline and the railway was urbanised, albeit not completely due to the presence of gardens and allotments.

Between 1920 and 1930 the coastline went through significant interventions: in the area next to the historical centre, between the old castle and Saline Gate, the small beaches were incorporated in $300 \mathrm{~m}$ long and $20 \mathrm{~m}$ wide embankments of the new sea promenade.

The embankments were identified through a detailed multi-temporal map comparison which allowed a precise reconstruction of the coastal dynamics.

The most important modifications took place between the 1950s and the 1980s, when the growing demand of tourist residences, which today represent $50 \%$ of property assets, resulted in rapid urban sprawl (Fig. 9). The increase of the builtup areas was sudden causing the almost total saturation of the floodplain and surrounding slopes up to $100 / 150 \mathrm{~m}$ a.s.l. If in the early nineteenth 


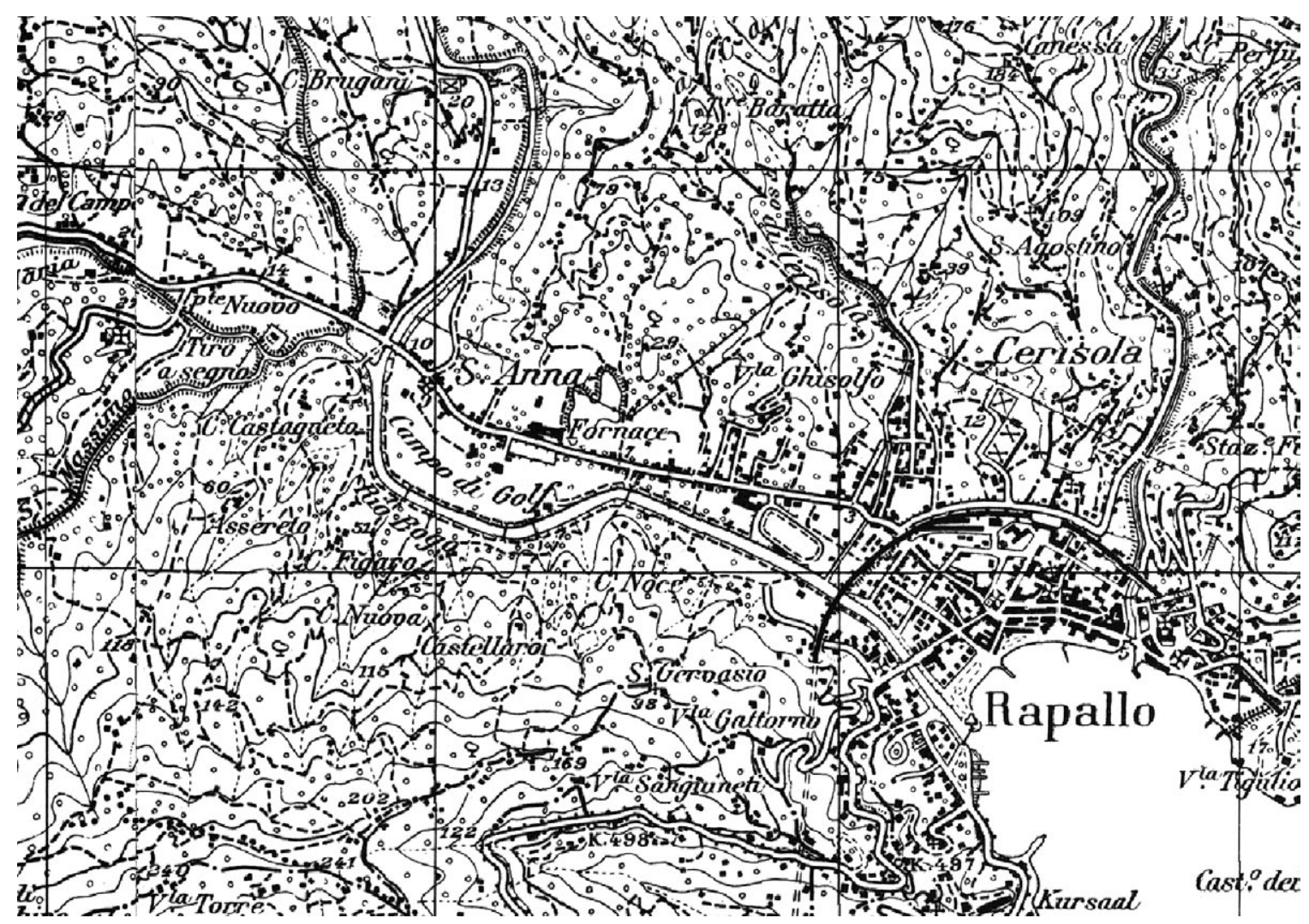

Fig. 8. Rapallo flood plain in the 1936s (after 1.25.000 scale map, IGMI Archives).

century the urban area was c. 45 ha, in 1957 it was 175 ha, reaching 600 ha in 1978 up to today's 650 ha (Fig. 10, 11).

The new urbanization of the terminal stretch of the San Francesco and Tuia Streams and of many tributaries of the Boate Stream entailed the culvert and channelling of riverbed; the whole Boate Stream floodplain is urbanised up to the confluence of its tributaries, the San Pietro and Santa Maria streams (Fig. 12).

Thank to the construction of a golf course in the 1920s, the right bank of the Boate Stream, between Sant'Anna and S. Maria was the only area

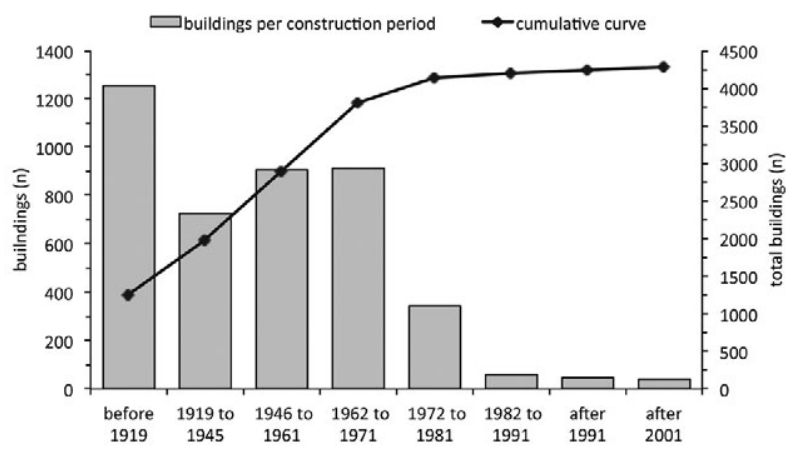

Fig. 9. Buildings of Rapallo per year of construction periods (from ISTAT census, 2011). preserved by the urbanization. The golf course, however, involved significant morphological modifications, with excavations, fillings and the diversion of San Massimo and S. Maria streams, which were diverted and rectified for c. $400 \mathrm{~m}$.

In the 1960s several fillings were made in the floodplain inland area and along the foothill; these works took advantage from the large amount of crushed rocks and materials from building activity and particularly from the construction of the motorway Genova-Livorno. The spoil of debris and rock from the motorway tunnels excavation was almost entirely used to fill the riverbed of Savagna Stream, next to the motorway entrance, that was diverted and culverted.

During 1960s and 1970s some limestone quarries affected in particular the slopes of S. Maria, S. Pietro and San Francesco Stream valleys, surrounding the inland sectors of the floodplain.

The last relevant morphological modification affected the shoreline in 1977 with the building of the new marina and the construction of a $600 \mathrm{~m}$ long breakwater which delimits an internal basin of c. 50,000 $\mathrm{m}^{2}$, about a third of the entire bay's area. This intervention included also the construction of a large embankment in the SW sector 


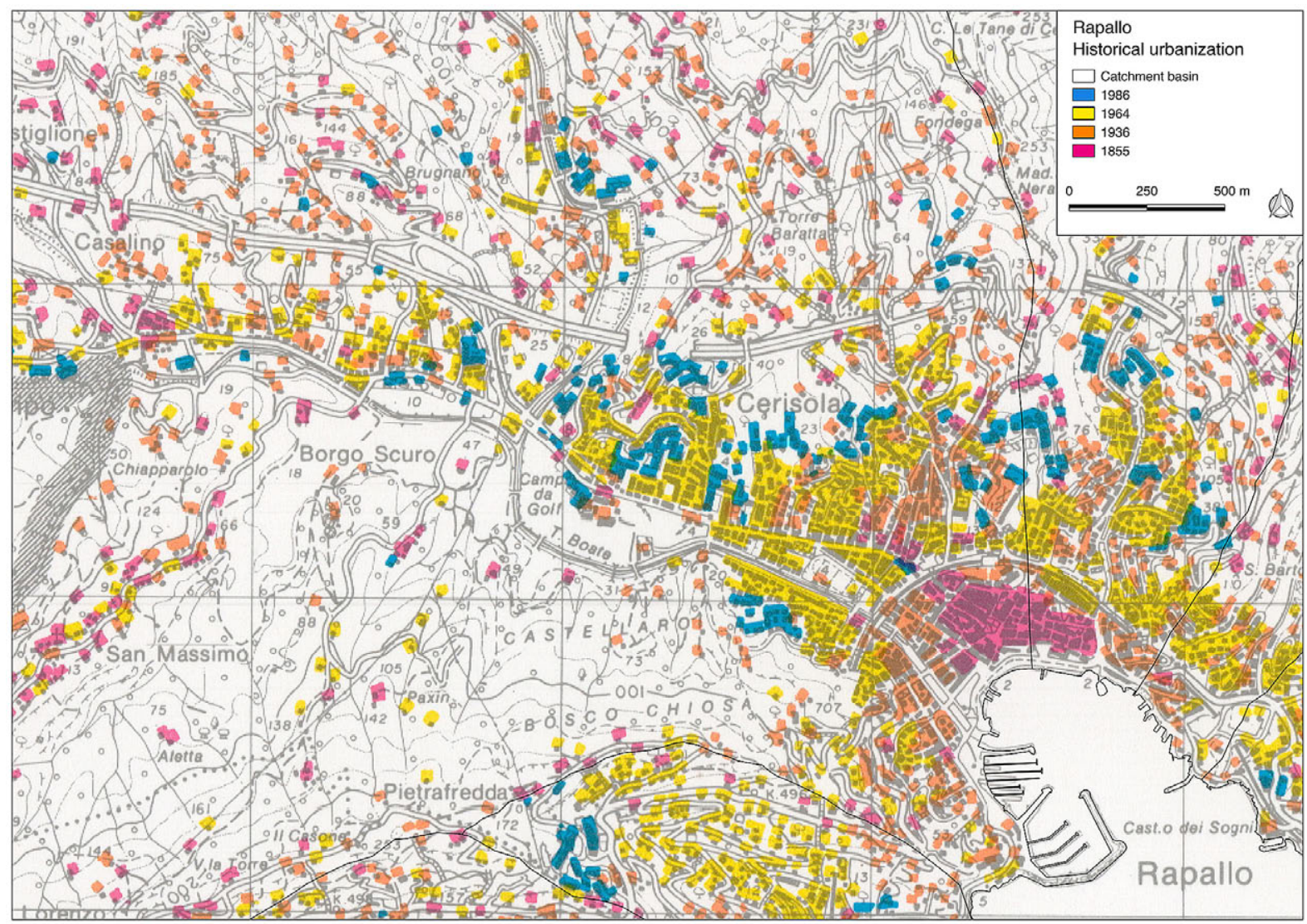

Fig. 10. Urban evolution map of Rapallo city from 1855 to 2000 (modified from Regione Liguria, 1986).

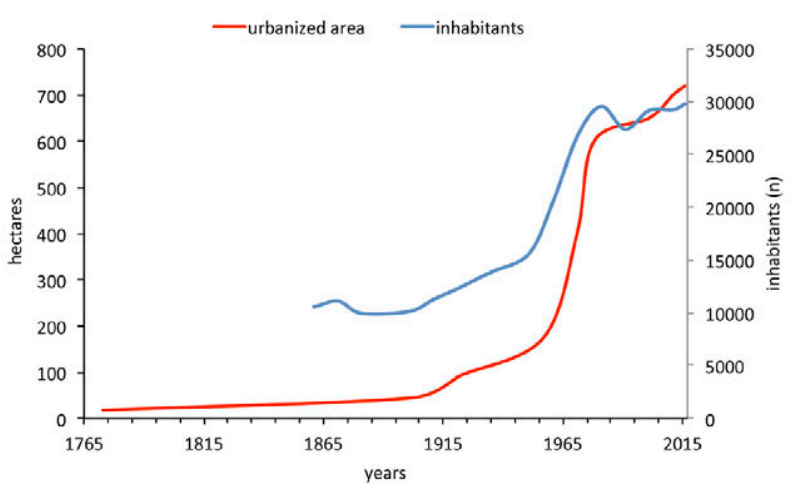

Fig. 11. Inhabitants and urbanization evolution of Rapallo floodplain.

of the bay, previously occupied by a beach and a rocky coast stretch, for a total extent of about $100 \mathrm{~m}$.

\section{Discussion and conclusions}

The collection and interpretation of the data obtained by multi-temporal maps and aerial photo comparison and by boreholes stratigraphy, integrated with documentation by Basin and Municipality Master Plans and with urban surveys, allowed the identification and mapping of the most significant morphological changes due to human intervention occurred in the coastal plain of Rapallo: if in the eighteenth century these changes were quite moderate, with low impact on former landforms, since the second half of nineteenth century and particularly after the 1950s, due to tourism exploitation, the coastal area of Rapallo underwent a sudden and radical change of geomorphological landscape.

The progressive urban sprawl had two major effects on the geomorphological setting of floodplain and surrounding slopes: 1) soil consumption and consequent soil sealing; 2) morphological modifications and creation of new man-made landforms (Fig. 12). The man-made landforms are mainly due to the straightening, diversion and channelling of streams (drainage network modifications), slope excavations, quarry activity, valley fillings, embankments (plain and slopes morphological modifications), sea embankments, harbour infrastructures, coastal defence and beach resorts (coastline modifications). 


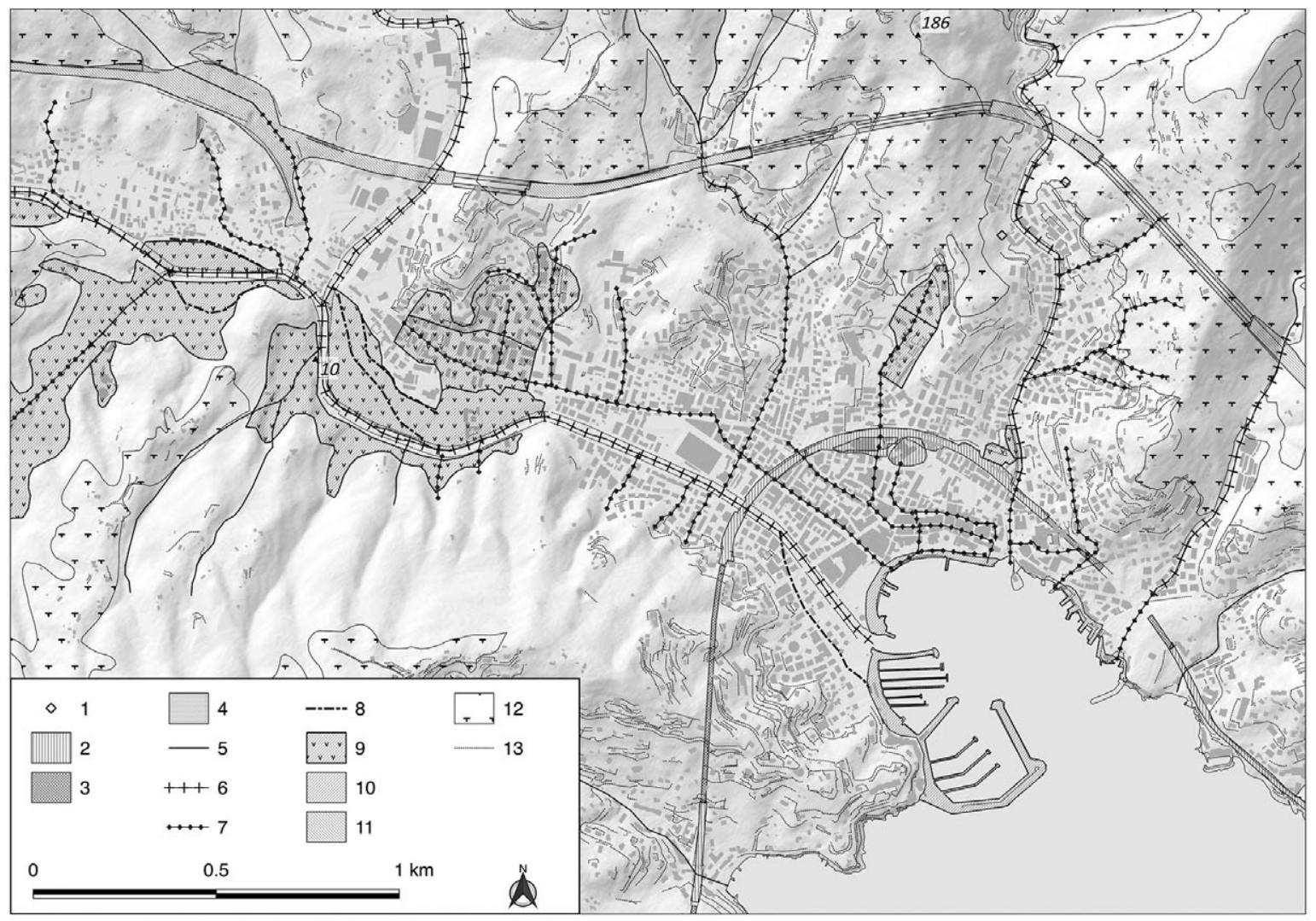

Fig. 12. Anthropocene sketch map of Rapallo city.

Man made landforms legend: 1) Quarry; 2) Railway excavation and embankment; 3) Railway tunnel; 4) Road tunnel; 5) Natural riverbed; 6) Concrete riverbed; 7) Culverted riverbed; 8) Abandoned stream; 9) Filling; 10) Sea embankment; 11) Road embankment; 12) Agricultural terraces; 13) Retaining walls.

Human activity and consequent land-use changes have strongly affected the former geomorphological conditions, inevitably modifying the water balance.

Referring to relation (Todd, Mais 2005):

$$
P=E+R+I
$$

where $\mathrm{P}$ is rainfall, $\mathrm{E}$ is evapotranspiration, $\mathrm{R}$ is surface runoff and $\mathrm{I}$ is infiltration, some

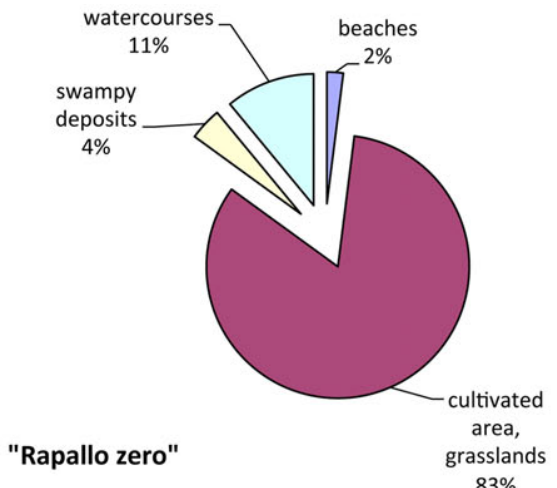

considerations on the variation of key components of the hydrological cycle pre- and post- urbanization of Rapallo can be highlighted.

Taking into account only the floodplain area and considering a mean annual rainfall and temperature with constant values, the average evapotranspiration for pre-urbanization conditions was calculated using the Turc and Coutagne relations; for the current conditions a $38 \%$ reduction of $\mathrm{E}$ for urban and peri-urban areas was introduced

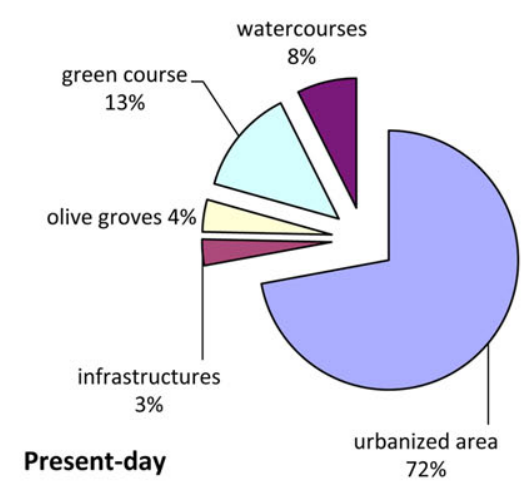

Fig. 13. Pie charts of land use of the floodplain at "Rapallo zero" and present-day conditions. 


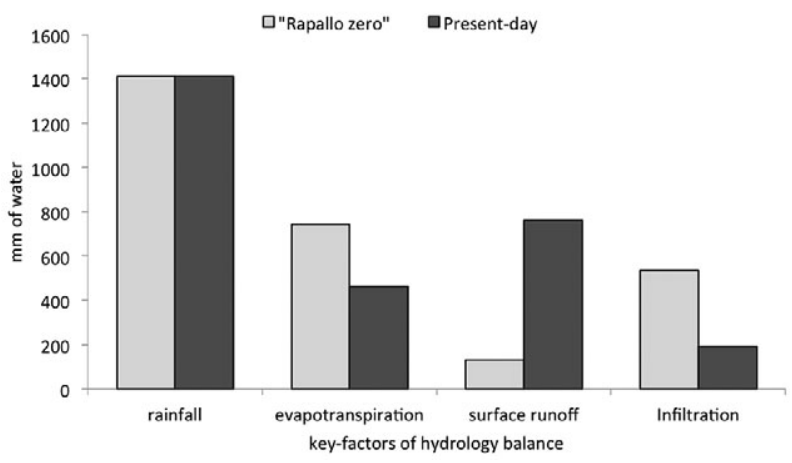

Fig. 14. Key factor of hydrology balance histogram at present-day and "Rapallo zero" land-use conditions of floodplain.

(Paoletti 2000). The current land use conditions were derived from the Basin Master Plan for geo-hydrological reduction (Città Metropolitana di Genova, 2015), while the pre-urbanization conditions were reconstructed with the analysis of late eighteenth and early nineteenth-century historical maps (Fig. 13). Based on land-use, some runoff coefficients were assigned: it is a dimensionless coefficient relating the amount of runoff to the amount of precipitation received. This assessment revealed an increase of the runoff by $>450 \%$ and a reduction of infiltration by $64 \%$ (Fig. 14) due to the floodplain urbanization.

The almost continuous urbanization, characterised by large blocks of flats (often without basements) built up all over the floodplain, due to the presence of clayey deposits with peat interlayers, caused both primary and secondary consolidation settlements; these vertical movements are still happening and they are estimated around $1 \mathrm{~cm} \mathrm{y}^{-1}$, partly due to water drainage activities for the aqueduct's wells, as emerged from the data on permanent scatterers and anomalous areas detected in the floodplain by the Risknat project (Available at RiskNET 2017) (Fig. 15).

Following urbanization, the whole drainage network along the floodplain and foot hill slope went through important modifications

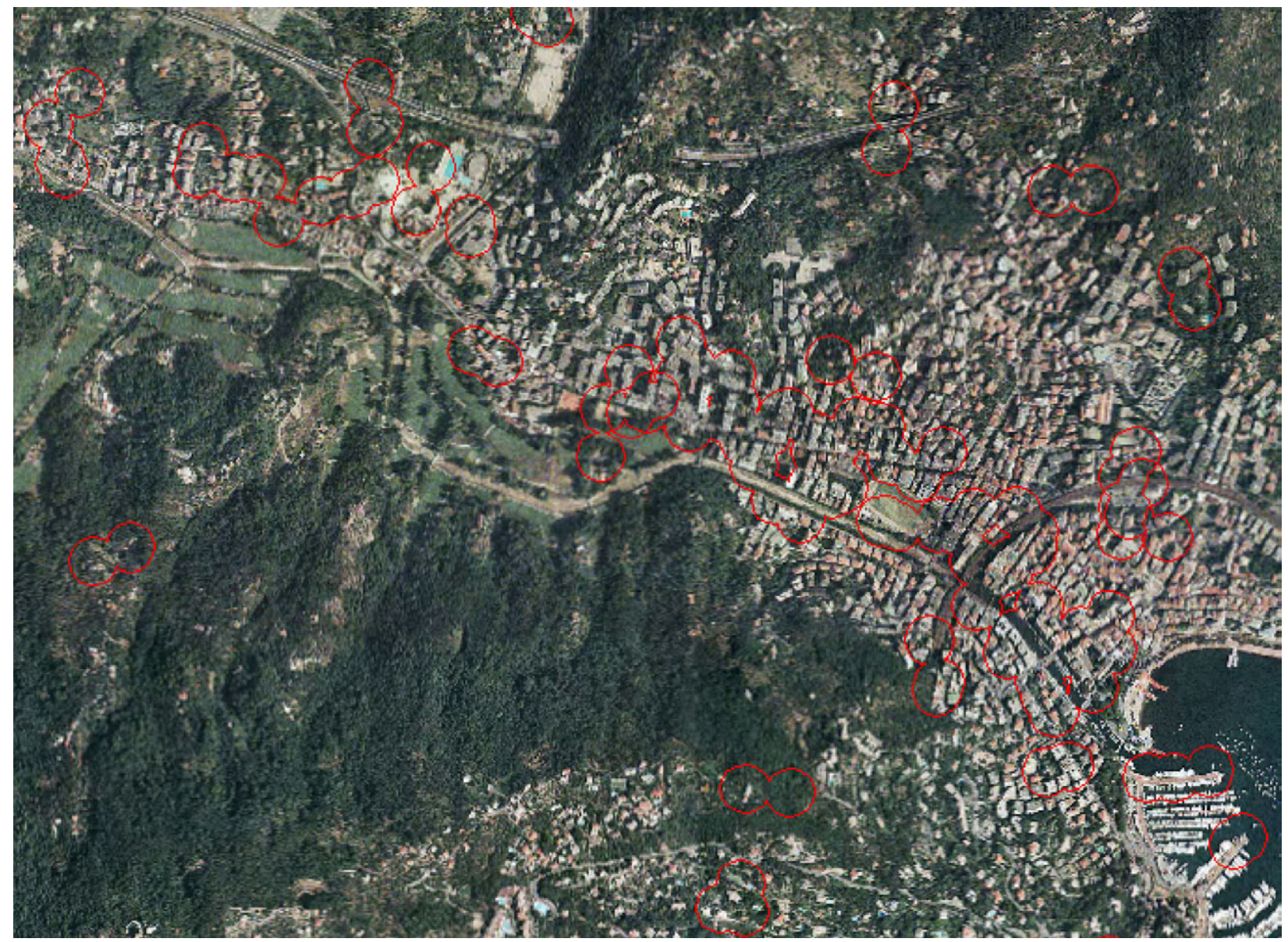

Fig. 15. Anomalous areas (red circles) detected in Rapallo floodplain by Risknat Project (DatasetPS_ENVI_D_ T208_F2709_RAPALLO,PS_ERS_A_T487_F891_VARESE_LIGURE, PS_ERS_D_T208_F2709_CAMOGLI).

(Available at RiskNET 2017). 
that, considering the rainfall regime and the morphological features of catchments surrounding Rapallo coastal plain, strongly impacted on streams dynamic and on geo-hydrological hazard (Brandolini et al. 2007, 2008, Brandolini, Cevasco, 2015). The channelling (by rectification) and the building of large embankment walls narrowed almost all the flow sections, affecting in particular the San Francesco and Boate streams, the latter being also affected by diversion in several segments. Moreover the San Francesco, Tuia and cereghetta Streams are today culverted in their terminal stretch. In most of the cases all these interventions along the drainage network, resulted in flow sections not adequate to control the peak flow discharge during high intensity rainfall events (Città Metropolitana di Genova 2015).

Eventually, the dense network of channels for irrigation which characterised the floodplain between the end of nineteenth century and the early twentieth century was completely dismantled: today the rainwater channel network is often inadequate to drain the rainfall to main stream network.

The effects of urbanization and morphological modifications and land use changes (Brandolini et al. 2017) increased geo-hydrological risk both in terms of vulnerability and hazard; the variation of the rainfall regime resulted in a more frequent occurrence of short but intense events increasingly concentrated in autumn (Faccini et al. 2005, Del Monte et al. 2015).

The floodplain of Rapallo has been historically affected by flood events which are both due to physical-geographical factors (high probability occurrence of rainstorms, small catchments, slope steepness, time of concentration less than 1 hour and almost unpredictable flood propagation) and to anthropic intervention (drainage network modifications).

Two floods, which affected Rapallo in October 1911 and September 1915, were particularly catastrophic. After these events, some works aimed to reduce geo-hydrological risk involved the building of embankments and water regulation of Boate Stream and its main tributaries. These structural interventions became part of the urban landscape but did not mitigate the flood risk and other events occurred, such as in October 1953, 1961 and 1995. Only in recent times, after 2000, further interventions counteracted flooding hazard. The concrete levees were raised, Boate stream riverbed was lowered in the terminal stretch and a bridge was demolished and replaced by a drawbridge. These works guarantee the discharge during floods with 50 years return period, therefore reducing geo-hydrological risk in a wide sector of the coastal floodplain of Rapallo.

We believe that urban geomorphological mapping and studies can provide good insights into urban planning policies, contributing to a more comprehensive evaluation of geo-hydrological issues, affecting highly built environment in coastal-hilly contexts such as the case of Rapallo city, and supporting the identification and prioritization of risk-mitigation measures, today even more crucial due to the rainfall regime variations.

\section{References}

Ballardini D., 1994. In burgo Rapalli. Documenti e monumenti di un borgo medievale (In Rapallo village. Documents and monuments of a medieval city). Ecig, Genova.

Bathrellos G.D., 2007. An Overview in Urban Geology and Urban Geomorphology. Proceedings of the $11^{\text {th }}$ International Congress, Athens, May, 2007. Bulletin of the Geological Society of Greece 40: 1354-1364.

Brandolini P., 1994. Le trasformazioni della piana costiera di Rapallo (Liguria Orientale) dal 1700 ad oggi: rapporti fra condizioni morfologiche ed interventi dell'uomo (The Rapallo coastal floodplain changes from 1700 to nowadays: relationships between morphology and human interventions). In: Citarella F. (ed.), Studi Geografici in onore di Domenico Rocco, Loffredo Editore, Napoli: 27-40.

Brandolini P., 1995. Modificazioni della fascia costiera compresa tra Portofino e Zoagli (Liguria Orientale) a seguito dello sviluppo turistico (Modifications of the coastal zone between Portofino and Zoagli following tourist development). Memorie della Società Geografica Italiana, Special Number n. 1 "Lo spazio costiero italiano. Problemi di crescita, sensibilità ambientale", Società di Studi Geografici, Firenze: 243-252.

Brandolini P., Canepa G., Faccini F., Robbiano A., Terranova R., 2007. Geomorphological and Geo-Environmental features of the Graveglia Valley (Ligurian Apennines, Italy). Geografia Fisica e Dinamica Quaternaria 30: 99-116.

Brandolini P., Faccini, Robbiano A., Terranova R., 2008. Relationship between flood hazards and geomorphology applied to land planning in the upper Aveto Valley (Liguria, Italy). Geografia Fisica e Dinamica Quaternaria 31: 73-82.

Brandolini P., Cevasco A., Firpo M., Robbiano A., Sacchini A., 2012. Geo-hydrological risk management for civil protection purposes in the urban area of Genoa (Liguria, NW Italy). Natural Hazards and Earth System Sciences 12: 943-959. Brandolini P., Cevasco A. 2015. Geo-hydrological Risk Mitigation Measures and Land-Management in a Highly Vulnerable Small Coastal Catchment. In: Lollino G. et al. (eds.), Engineering Geology for Society and Territory. Springer International Publishing Switzerland, 5: 759-762. 
Brandolini P., Cevasco A., Capolongo D., Pepe, G. Lovergine F., Del Monte M. 2017. Response of terraced slopes to a very intense rainfall event and relationships with land abandonment: a case study from Cinque Terre (Italy). Land Degradation \& Development: 1-27. DOI: 10.1002/ldr.2672.

Brown A.G., Tooth S., Bullard J.E., Thomas D.S.G., Chiverrell R.C., Plater A.J., Murton J., Thorndycraft V.R.,Tarolli P., Rose J., Wainwright J., Downs P., Aalto R., 2017. The geomorphology of the Anthropocene: emergence, status and implications. Earth Surf. Process. Landforms 42: 71-90. DOI: 10.1002/esp.3943.

Chengtai D., 1996. An approach to theory and methods of urban geomorphology. Chinese Geographical Science 6 (1): 88-95.

Cimmino F., Faccini F., Robbiano A., 2004. Stones and coloured marbles of Liguria in historical monuments. Per. Mineral. 73 (Special Issue 3: a showcase of the Italian research in applied petrology): 71-84.

Città Metropolitana di Genova, 2015. Piano di Bacino Ambito 15 , piano stralcio per la tutela dal rischio idrogeologico di cui all'art. 1, comma 1 del D.L. n. 180/1998 convertito in Legge n. 267/1998 e s.m.i. Available at: http:/ / www.pianidibacino.ambienteinliguria.it/GE/ambito15/ambito15. html.

Coates D., 1974. Environmental geomorphology and landscape conservation, Vol. 2, Urban areas, Pennsylvania, U.S.A., Hutchinson \& Ross, Stroudsburg, Dowden.

Coates D., 1976. Urban Geomorphology. Colorado, US.A. Geological Society of America, Sp. Paper 174.

Comune di Rapallo, 2014. Studi Geologici a supporto del Piano Urbanistico Comunale. Progetto definitivo.

Cooke R.U., 1976. Urban geomorphology. Geographical Journal 142 (1): 59-65.

Cooke R.U., Brunsden D., Doornkamp J.C., Jones D.K.C., 1982. Urban geomorphology in drylands. University Press, Oxford.

Cortemiglia G.C., Terranova R., 1974. Aspetti geomorfologici, idrologici ed oceanografici del Golfo di Rapallo (Geomorphogical, hydrological and oceanographic aspects of the Gulf of Rapallo). Atti della Società italiana di scienze naturali: 285-384.

Crutzen PJ., 2002. Geology of mankind. Nature 415: 23. DOI:10.1038/415023a

Del Monte M., D'Orefice M., Luberti G.M., Marini R., Pica A., Vergari F. 2016. Geomorphological classification of urban landscapes: the case study of Rome (Italy). Journal of Maps 12: 178-189.

Del Monte M., Fredi P., Pica A., Vergari F. 2013. Geosites within Rome City Center (Italy): a mixture of cultural and geomorphological heritage. Geografia Fisica e Dinamica Quaternaria 36: 241-257.

Del Monte M., Vergari F., Brandolini P., Capolongo D., Cevasco A., Ciccacci S., Conoscenti C., Fredi P., Melelli L., Rotigliano E., Zucca F. 2015. Multi-method evaluation of denudation rates in small mediterranean catchments. Engineering Geology for Society and Territory - Vol 1: Climate Change and Engineering Geology: 563-567.

Ellison R.A., Booth S.L., Strange P.J., 1993. Geological mapping in urban areas. Episodes 16 (3): 383-387.

Eyles N., 1997. Environmental geology of urban areas. Newfoundland, Canada, Geological Association of Canada, Geotext 3.

Faccini F., Brandolini P., Robbiano A., Perasso L., Sola A., 2005. Instability, precipitation phenomena and land planning: The flood of 2002 in lower Lavagna valley (Eastern Liguria, Italy) [Fenomeni di dissesto e precipitazioni in rapporto alla pianificazione territoriale: L'evento alluvion- ale del novembre 2002 nella bassa val Lavagna. Geografia Fisica e Dinamica Quaternaria Suppl. 7: 145-153.

Faccini F., Luino F., Sacchini A., Turconi L., De Graff J. V., 2015. Geohydrological hazards and urban development in the Mediterranean area: an example from Genoa (Liguria, Italy). Natural Hazards and Earth System Sciences 15(12): 2631-2652. DOI: 10.5194/nhess-15-2631-2015.

Faccini F., Giostrella P., Melillo M., Sacchini A., Santangelo M., 2017. Heavy rains triggering flash floods in urban environment: a case from Chiavari (Genoa Metropolitan area, Italy). Italian Journal of Engineering Geology and Environment, Special Issue: 51-66. DOI: 10.5194/nhess-15-2631-2015.

Gruppo Nazionale Geografia Fisica e Geomorfologia, G.B. Pellegrini, A. Carton, D. Castaldini, A. Cavallin, L. D'Alessandro, F. Dramis, B. Gentili, L. Laureti, A. Prestininzi, G. Rodolfi, U. Sauro, M. Sorriso Valvo, V. Spagna (Eds.), 1993. Proposta di legenda geomorfologica ad indirizzo applicativo. Geografia Fisica e Dinamica Quaternaria 16: 129-152.

Laureti L., Sauro U., Terranova R., Brandolini P., Firpo M., Pirola A., Piccazzo M., Rossetti R., Smiraglia C., 1996. The physical change in the Mediterranean basin with particular reference to Italy. Conference of the International Geographical Union (IGU), Moscow, Russia, August 14-18, 1995, Bollettino Societá Geografica It., serie XII, 1: 7-44.

Luino F., Nigrelli G., Turconi L., Faccini F., Agnese C., Casillo F., 2016. A proper land-use planning through the use of historical research. Disaster Advances 9(1): 8-19.

Marini M., 1981. Analisi geologica-strutturale ed interpretazione paleogeografica e tettogenetica dei Calcari del Monte Antola (Appennino Ligure) (Geological-structural analysis and palaeogeographic and tectogenetic interpretation of the Calcari del Monte Antola (Appennino Ligure). Ofioliti 6 (1): 119-150.

Paoletti A., 2000. Risorse idriche ed impatto ambientale del drenaggio urbano (Water resources and environmental impact of urban drainage). In: Paoletti A. (ed.) Atti delle giornate di studio in memoria di Carlo Cao, Cagliari 18-20 novembre 1998, CDSU, Milano.

RiskNET Fondazione Montagna Sicura, 2017. Online: www. risknet-alcotra.org (accessed 21 July 2017).

Sacchini A., Ferraris F., Faccini F., Firpo M., 2012. Environmental climatic maps of Liguria. Journal of Maps 8 (3): 199-207. DOI: http://dx.doi.org/10.1080/17445647.2012.703901.

Scarin F., 1959. Rapallo, nota di Geografia Urbana. Annali di Ricerche e Studi di Geografia: 189-214.

Servizio Geologico Nazionale, 1994. Carta geomorfologica d'Italia, scala 1:50.000, Guida al rilevamento (Geomorphological map of Italy at 1:50,000 scale, Survey guide). Quaderni serie III, 4, Istituto Poligrafico e Zecca dello Stato, Roma.

Terranova R., Piccazzo M., Firpo M., Brandolini P., 2000. Coastal change in global change: the case of Italy. In Vol. Geographies of diversity, Italian perspectives, Geo-Italy 4. Società Geografica Italiana e CNR - Italian Committee for IGU, published in occasion of the I.G.U. International Conference, Seoul: 305-321.

Todd D.K., Mais L.W., 2005. Groundwater hydrology. $3^{\text {rd }}$ edition. John Wiley \& Sons Inc., New Jersey (USA).

Waters C.N., Zalasiewicz J.A., Summerhayes C., Barnosky A.D., Poirier C., Gałuszka A., Cearreta A., Edgeworth M., Ellis E.C., Ellis M., Jeandel C., Leinfelder R., McNeill J.R., deB R.D., Steffen W., Syvitski J., Vidas D., Wagreich M., Williams M., Zhisheng A., Grinevald J., Odada E., Oreskes N., Wolfe A. 2016. The Anthropocene is functionally and stratigraphically distinct from the Holocene. Science 351: aad2622. DOI:10.1126/science.aad2622. 